\title{
How Much Do the "Best" Colleges Spend on Libraries? Using College Rankings to Provide Library Financial Benchmarks
}

\section{Yvonne Jones}

Recent ACRL guidelines ${ }^{1}$ and standards ${ }^{2}$ urge academic librarians to compare selected input and output measures with peer institutions for assessment. This paper provides an example of such a comparison, using a freely available statistical tool from the National Center for Education Statistics (NCES). ${ }^{3}$ Applying the NCES data tool to liberal arts colleges chosen by U.S. News and World Report (USN\&WR) ${ }^{4}$ as the "Best Liberal Arts Colleges" provides one strategy for choosing financial benchmarks to target, as well as staffing and output measures for comparison. Using liberal arts colleges ranked in the top third by USN\&WR, about $\$ 2,000$ / FTE would be the 2004 reported amount that the "best" colleges spent on library resources.

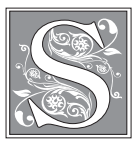

ince 1959, the Association of College \& Research Libraries (ACRL) has developed standards and guidelines to aid academic librarians in assessing their libraries. Most recently, in June 2005, “Guidelines for University Library Services to Undergraduate Students" was approved. These guidelines follow the approval in June 2004 of "Standards for Libraries in Higher Education. ${ }^{\prime 6}$ Both of these documents provide approaches for assessing the academic library based on selected input and output measurements. Both documents urge librarians to use both quantitative and qualitative assessment tools and suggest comparison with peer institutions. This paper presents one mechanism available through the
National Center for Education Statistics (NCES) for such peer comparisons on various statistical parameters. The NCES Library Statistics Program "Compare Academic Libraries" peer evaluation data tool $^{7}$ is freely available on the Web and provides data from the 2004 Academic Library Survey. One goal of this paper is to publicize the availability of this data tool to the library community. This online tool makes it possible to easily examine free statistical resources to provide benchmarks on financial expenditures and staffing for libraries. Such comparisons and benchmarks are necessary components of library budget planning and funding requests.

This paper presents a mechanism for the peer comparisons that are encouraged

D. Yvonne Jones is Reference Librarian in the Olin Library at Rollins College; e-mail: djones@rollins.edu. 
for library assessment. Some academic libraries are already members of various consortia or groups that constitute reasonable peer comparisons using already established informal communication networks. Such an informal network may not be the most appropriate or accessible for all academic libraries, however. All libraries could reasonably consider the question of to whom they would like to compare themselves. This paper demonstrates a comparison group using an evaluation of college rank unrelated directly to library assessment. The U.S. News \& World Report (USNEWR) annual list of "best" colleges ${ }^{8}$ uses criteria that do not directly measure any library parameters. In the formula used by USNEWR to produce their college rankings, ten percent of the score is derived from overall financial resources, ${ }^{9}$ which, of course, do impact libraries. However, there is no assessment as to how each college apportions its available financial resources; thus, no direct measure of library financial resources is possible.

The assumption is made in this paper that the "best" colleges based on an aggregate of characteristics other than library variables will also be those colleges that provide the "best" library resources and experiences. While this assumption could be refuted and almost assuredly does not hold true in particular instances, it seems reasonable to link overall excellence in a college with expected excellence in that college's library. The use of this USNEWR list provides us with an independent ranking from which to compare library resource inputs and outputs. Thus, this strategy provides a quantitative objective measure of assessment and one way of providing a ranking of library resources for liberal arts colleges.

Although USNEWR provides ranking for universities and comprehensive colleges in addition to liberal arts colleges, this paper focuses on liberal arts colleges for two reasons. First, typically a single library is found on a liberal arts campus in contrast with universities and institutions offering graduate degrees where several library buildings and specialized libraries are often present. The simpler situation of a single library seemed more appropriate for an initial presentation of a comparison mechanism. In addition, universities and research libraries already have library income and expenditure data from 1908 to 2004 available through the Association of Research Libraries (ARL). ${ }^{10}$

\section{Methods}

This study compares the top 50 liberal arts colleges from the 2004 U.S. News $\mathcal{E}$ World Report ranking ${ }^{11}$ with publicly available online data from the National Center for Education Statistics, data obtained during the Academic Libraries Survey Fiscal Year 2004. ${ }^{12}$

\section{U.S. News \& World Report Data:}

The August 30, 2004, USNEWR ${ }^{13}$ published an article entitled "America's Best Colleges" which ranked more than 1,800 schools in four categories: national universities-doctoral, universities-master's, comprehensive colleges-bachelor's, and liberal arts colleges-bachelor's. This paper focuses on the 217 liberal arts colleges. After evaluating and scoring these 217 colleges, USNEWR listed the top-ranked 50 . Four of the colleges listed were not included in this analysis (Pomona College, Claremont McKenna College, Harvey Mudd College, and Scripps College), as these colleges are part of the California Claremont Colleges Consortium and share several libraries' resources across the constituent colleges. The Claremont Colleges were all highly rated but, because of their unique structure, did not fit this analysis. The remaining list of 46 colleges was divided roughly into thirds, with the top third constituting 15 colleges with overall scores of 83 to 100 and ranks from 1 to 16 . The middle third was 15 colleges with scores from 73 to 82 and ranks from 19 to 33. The bottom third was 16 colleges with overall scores from 65 to 71 and ranks from 35 to 50 . Ranks were not necessarily continuous, as several colleges 
shared the same score and the same rank. Thus, the next rank would be several numbers higher, reflecting the number of colleges with the same score. The specific colleges from the USNEWR utilized in this paper are shown in Appendix A.

\section{National Center for Education Statistics Data:}

NCES currently collects data every two years from about 3,700 colleges and universities. Summaries and detailed reports of the results of the Academic Library Surveys are available online along with public-use data files $h t t p: / / n c e s . e d . g o v / s u r-$ veys/libraries/Academic.asp). The most recent data to which the NCES provides access are the 2004 Academic Libraries Survey data, which are obtained through the use of the online statistical tool "Compare Academic Libraries"14 (http://nces. ed.gov/surveys/libraries/compare/index. asp?LibraryType=Academic).

This online tool allows peer comparisons to be easily conducted. The researcher can choose a library of interest and then select specific libraries for comparison by name or by a particular variable of interest (for instance, Carnegie classification, or geography). The data tool provides tables of results that can be sorted and produce basic bar charts or the researcher can export results to an Excel file for further statistical analysis. The entire process of data manipulation is clearly explained and easily conducted with this free online tool.

In the 2004 NCES Academic Library Survey data, about 3,700 libraries were surveyed. One of the categorizing variables for the surveyed libraries was their Carnegie Classification. Those libraries with a Carnegie Classification of Baccalaureate Liberal Arts $(\mathrm{N}=216)$ were included as the NCES-Liberal Arts College Libraries in the analyses of this study. The total responding libraries $(\mathrm{N}=3,700)$ constitute the NCES-All Academic Libraries group. The 2004 Academic Library Survey presented question results in nine major categories: Identifying Informa- tion, Academic Library Characteristics, Academic Institution Characteristics, Geography, Electronic Services and Technology, Paid Full-Time Equivalent Staff (FTE), Expenditures, Size of Collection, and Services. For this analysis, five variables were selected as input measures to assess. These variables were: "Total Library Expenditures," "Total Library Expenditures/FTE," "Librarians and Other Professional Staff/1000 FTE," "Total Staff/1000 FTE," and "Books and Other Paper/FTE." Comparison of output measures also utilized five variables: "Annual Circulation Transactions/FTE," "Annual ILL (Interlibrary Loans) Provided," "Annual ILL Received," "Reference Transaction/Typical Week," and "Gate Count/Typical Week." "Total 12-Month FTE Enrollment" was included as a control descriptive variable.

\section{Results}

A comparison of the FTE enrollments across the three groups of USNEWR ranked colleges and the NCES-Liberal Arts College Libraries and NCES-All Academic Libraries showed little difference within the USNEWR top-ranked college libraries in FTE enrollment (see table 1). Mean and median values within these three groups also differed only slightly. In contrast, the larger groups of NCES-Liberal Arts College Libraries $(\mathrm{N}=216)$ and NCES-All Academic Libraries $(\mathrm{N}=3,700)$ showed right-skewing of values, with higher mean than median results. Both mean and median values in the NCESLiberal Arts group were slightly lower than the top-ranked libraries. For the NCES-All Academic Libraries, the median FTE enrollment was similar to the NCES-Liberal Arts median value, while the mean was over twice the median value. This is not surprising given that the NCES-All Academic Libraries includes major universities with high enrollments. However, given these results for the FTE control variable, it was decided to report both mean and median values for all variables examined. 


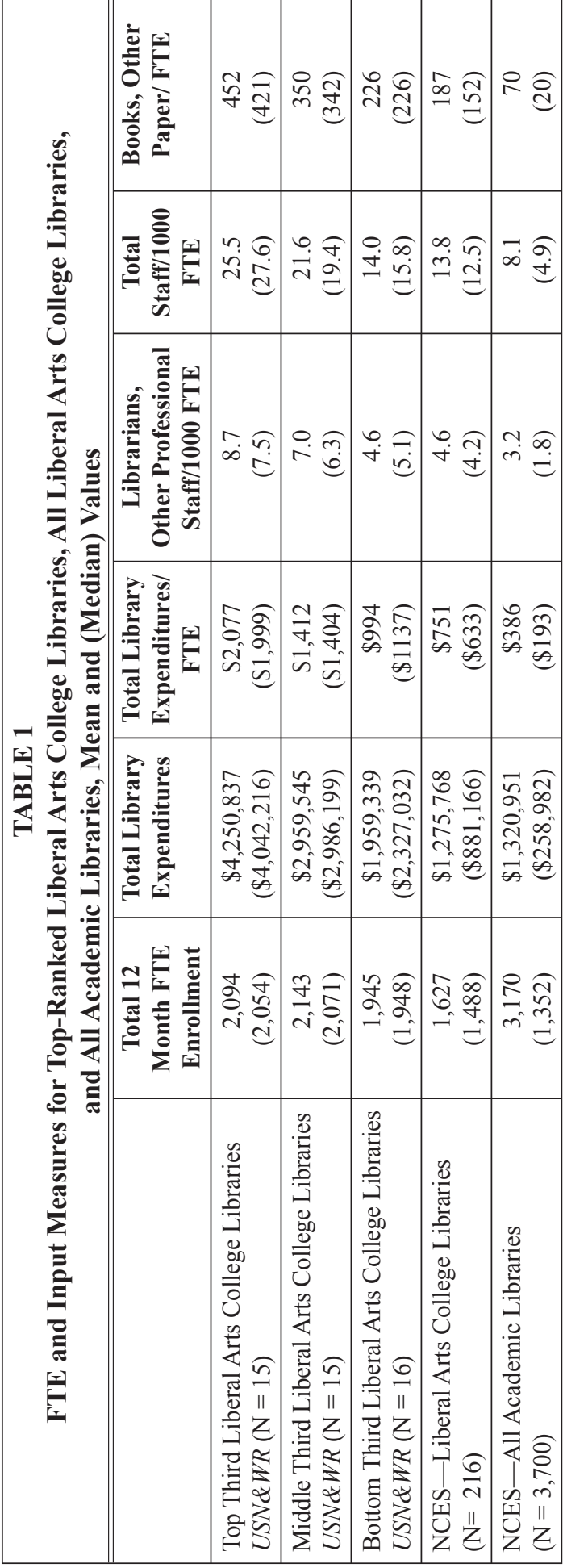

Results from the input measures (shown in table 1) typically follow a stepwise pattern, from highest values in the top third of USNEWR libraries down to lowest values in the comparison with NCES-All Academic Libraries. One exception to a direct stepwise decrease in value going down the table is in "Total Library Expenditures." While there is a linear decrease in expenditures if the median values are considered, mean values show a slightly higher expenditure for the NCES-All Academic Libraries group compared with the NCES-Liberal Arts College Libraries group. The other four input measures show a consistent stepwise decrease in magnitude from the highest values observed in the top third of the USNEWR ranked college libraries to the lowest values in the NCES - All Academic Libraries. In the case of the variable "Librarians, Other Professional Staff/1000 FTE," there is a plateau, with the bottom third of the USNEWR college libraries and the overall NCES-Liberal Arts College Libraries group both sharing a value of 4.6 .

Results for the output measures examined (shown in table 2) provide a more mixed picture. Three output measures showed a clear decrease of both mean and median values down the table: "Annual Circulation Transactions/FTE," "Annual ILL Provided," and "Annual ILL Received." "Reference Transactions/Week" showed higher values for the top two thirds of the USNEWR group, while the bottom third of the USNEWR ranking and the NCES-Liberal Arts College Libraries group were es- 
sentially the same and about 40 percent lower in value than the top two USNEWR groups. The NCES-All Academic Libraries category had the highest mean value for this variable coupled with the lowest median value, showing significant right-skewing of this measure. The output variable "Gate Count/Week" demonstrated the most mixed result, with the three USNEWR groups all exhibiting high values, but the highest in the middle group. The NCES-Liberal Arts College Libraries group and the NCES-All Academic Libraries group were roughly comparable in mean value and reported "Gate Counts/Week" about 45 percent lower than the USNEWR groups (based on the mean counts). Their median values differed markedly, with the NCES-Liberal Arts College Libraries showing 65 percent lower counts and the NCES-All Academic Libraries showing almost 90 percent lower gate counts compared with the USNEWR groups.

\section{Discussion}

In the 2005 "Guidelines"15 paper, the ACRL Undergraduate Librarians Discussion Group specifically urges librarians to "...choose their own peer libraries for the purpose of comparisons, depending on the needs of the library." After determining appropriate peer libraries for comparison, several "possible points of comparison" are presented. The first listed point of comparison for input measures is budget and staffing, while the first two listed comparison points for output measures are reference transactions/FTE and borrowing (excluding reserve)/

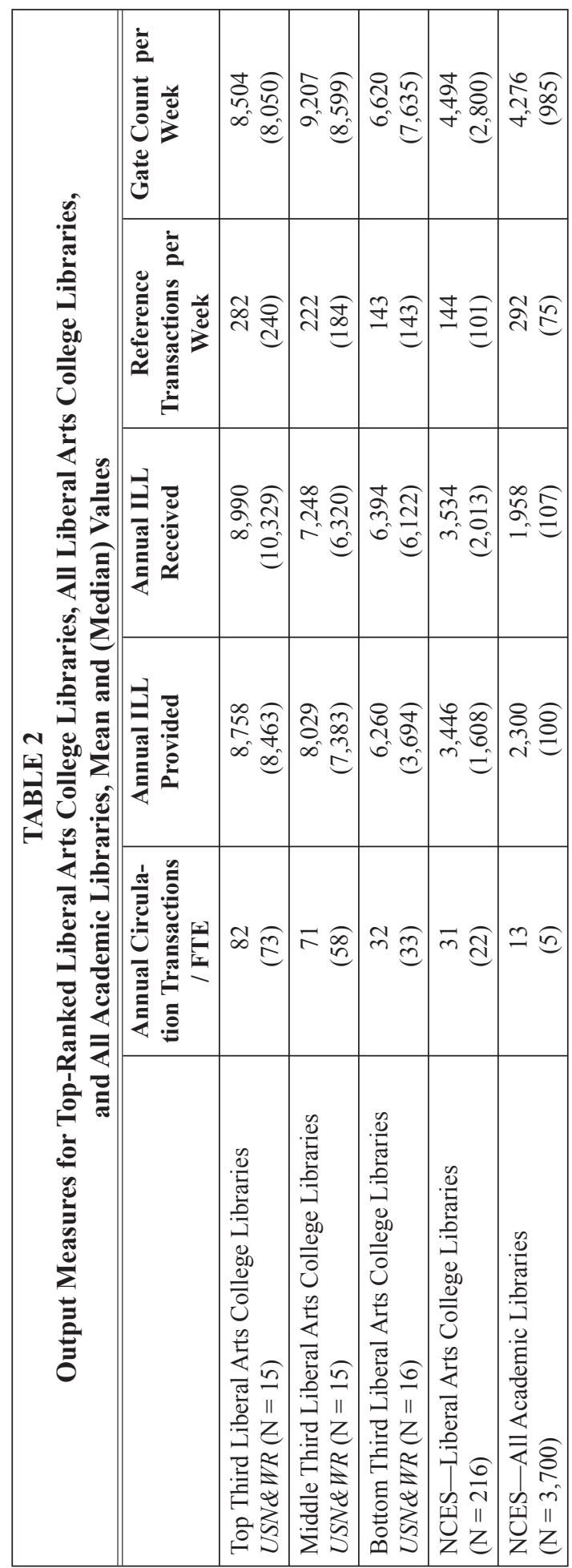


FTE. The NCES Academic Library Survey provides data to evaluate each of these measures. Similarly, in the 2004 "Standard for Libraries in Higher Education" paper, ${ }^{16}$ the ACRL Board of Directors encourages each library to "...choose its own peer group for the purpose of comparisons." The first suggested comparison point for input measures described in this document is the "ratio of volumes to combined total student (undergraduate and graduate, if applicable) and faculty FTE." Other comparison points enumerated include the "ratio of material/information resource expenditures to combined total student and faculty FTE" and the "ratio of FTE library staff to combined student and faculty FTE." Recommended output measures for comparison included the "ratio of circulation (excluding reserve) to combined student and faculty FTE," the "ratio of interlibrary loan request to combined student and faculty FTE," the "ratio of interlibrary loan lending to borrowing," and the "ratio of reference questions (sample week) to combined student and faculty FTE." The NCES Academic Library Survey gathered information about each of these recommended measures. Moreover, the NCES "Compare Academic Libraries" data tool provides an accessible and easily used mechanism for actually carrying out peer comparisons.

A comparison of five NCES Academic Library Survey variables expressing input measures of budget, staffing, and materials is given in table 1. Total FTE enrollment is also shown to provide a measure of size of the institution. In the comparison groups chosen for this paper, all three groupings of the top-ranked USNEWR liberal arts colleges enrolled about 2000 students annually. The total enrollment for the 216 liberal arts colleges surveyed by NCES was about 1,600 students and the enrollment for NCES-All Academic Libraries showed right-skewing of the data very markedly, with a mean enrollment of over 3,000 students but a median value of 1,352 . For comparisons within the liberal arts colleges category, there is little reason to correct for size (reflected by FTE). However, comparison with the NCES-All Academic Libraries group requires correction for FTE, which is done for four of the input variables.

Total library expenditures showed a clear step-down pattern from a 2004 annual budget of about $\$ 4$ million for the top third of the USNEWR ranked liberal arts colleges, to about $\$ 3$ million for the middle third, \$2 million for the bottom third USN\&WR ranked colleges and about \$1 million for NCES-Liberal Arts College Libraries. The total budget for NCES-All Academic Libraries showed a slightly higher mean value (\$1.3 million), but significantly lower median value $(<$ \$260K) in comparison with NCES-Liberal Arts College Libraries. Correcting for FTE resulted in a clear decrease from about \$2K per student in the top third USN\&WR colleges, to $\$ 1.4 \mathrm{~K}$ in the middle third, $\$ 1 \mathrm{~K}$ in the bottom third, $\$ 600-\$ 800$ in the NCES-Liberal Arts College Libraries, and \$200-\$400 for NCES-All Academic Libraries. These two input variables provide clear benchmarks for comparison regarding budget, based on the peer colleges chosen. The other three input variables of staffing (professional and total) and materials corrected for FTE exhibited a near perfect step-down pattern in both mean and median values from the top third USNEWR ranked colleges to the comparison with all academic libraries.

This clear pattern of higher expenditures and resources in the higher-ranked colleges begs the question whether the ranking is merely a surrogate for income. Is ranking colleges in the USNEWR way the same as ranking by "Total Library Expenditures/FTE"? Using the NCES "Compare Academic Libraries" data tool, this question was explored. If you rank the liberal arts colleges assessed in the 2004 Academic Libraries Survey in descending order from the highest "Total Library Expenditures/FTE," the top 22 listed colleges include all ten of the top USNEWR colleges. The highest-ranked liberal arts college for "Total Library 
Expenditures/FTE" was ranked ninth in the USNEWR listing. In the top 50 listed Academic Library Survey colleges, there are 36 also on the USNEWR top list. Thus, although there is significant concordance, the USNEWR ranking is not a simple reflection of total library expenditure per student.

The step-down pattern seen in input measures (table 1) is not as evident when output measures (table 2) are examined. In the output measure "Annual Circulation Transactions/FTE," there are substantially more circulation transactions for the top two USNEWR groupings in comparison with the lower third and combined liberal arts colleges. The value for NCES-All Academic Libraries is in a category all of its own at the very bottom. It is difficult to interpret these results, however, as materials do not circulate in some specialized academic libraries. In fact, for all the output measures assessed, the interpretation of the highly skewed results obtained for the NCES-All Academic Libraries group is questionable. Meaningful comparisons for the output measures should be restricted to the upper four groups of liberal arts colleges, which share a single library with circulating collection and general academic focus. The NCES-All Academic Libraries group is included for general interest and consistency with table 1 presentation, but it encompasses too diverse a group to make useful conclusions.

Both the interlibrary loan (ILL) variables show a regular step-down pattern from the top third USNEWR group through to NCES-All Academic Libraries. "Annual ILL Provided" is reasonably linked with a library's collection size (which the input variable "Books, Other Paper/FTE" represents). Larger collections provide more ILL. One might also generally suggest that higher "Annual ILL Received" indicates more extensive library-based research by faculty and students at an institution.

The "Reference Transactions/Week" variable results follow somewhat the trend observed in the circulation transactions, with the top two USNEWR groups showing higher values and the bottom USNEWR group and total liberal arts colleges having similar lower values. However, unlike the circulation results, NCES-All Academic Libraries reports the highest mean value for reference transactions (along with the lowest median). Interpretation of this result should be cautious, as mentioned previously the tremendous diversity in the NCES-All Academic Libraries group is influencing this result. In addition, of course, these output variables are not corrected for FTE and the NCES-All Academic Libraries group has a significantly higher mean FTE than the other comparison groups.

In "Gate Count/Week" the pattern shifts slightly with both top USNEWR groups markedly higher than the bottom third USNEWR group or the general liberal arts college group. The bottom USNEWR group shows over 2,000 counts more than the NCES-Liberal Arts College Libraries group. Even taking into account that these variables of reference transaction and gate count were not corrected for FTE (in order to give values in an easily understandable numeric range), the lower values observed are considerably greater than the small difference in FTE between these groups. These output variables seem, indeed, to reflect a measure of quality performance that is evident in the top-ranked USNEWR colleges. It is interesting to note that these variables do not march in lockstep with the financial expenditures examined in table 1. However, they do share a similar pattern with the staffing input variables from table 1, suggesting an obvious link between staffing and reference transactions and a more intriguing link with gate count. Clearly the top-ranked colleges are doing something indeed "best" in these output measures.

\section{Conclusion}

While providing a quantitative mechanism for library assessment and compari- 
son, this paper hopes to contribute to the general discussion of what constitutes a "best" library and what resources are necessary. Recognizing that there is much involved in assessing a library other than financial measures and quantitative totals of transactions, recognizing that the mere process of "rating and ranking" may be offensive in nature to some librarians, it is still necessary to admit the realities of the economic world. A recent article presenting the rankings of research libraries cautions the reader that " ... rankings don't measure the quality of a library experience." ${ }^{17}$ Absolutely true. While the quality of the library experience for any particular person may be determined by a single parameter, such as interaction with staff or accessibility of resources, determining the overall quality of a library requires a combination of quantitative measures complemented by qualitative assessments. Several excellent recent books address techniques for such comprehensive assessments. ${ }^{18-20}$ However, a single measure such as ranking can provide one valuable benchmark for identifying a quality library.

In this analysis, the rankings used were unrelated directly to typical measures used in library rankings, such as the Association of Research Libraries' rankings. Number of volumes, number of staff, and expenditures are common ranking variables. These variables have been examined here using a group of top-ranked liberal arts colleges, where the ranking was based on college attributes as a whole with no direct library measurement component. The analyses presented here show that the top-ranked colleges did indeed exhibit typically higher expenditures, greater book numbers, and higher staff numbers per student. However, these "best" colleges also exhibited greater gate counts, circulation, and reference transactions, output measures not directly linked to resource capital.

Although the USNEWR rankings were used in this analysis to identify "best" colleges for comparison, any single library could have been selected for comparison or any group of libraries based on responses to a particular variable. The NCES "Compare Academic Libraries" data tool is completely flexible for the user to define the peer group of interest and the variables of interest. What is extremely valuable for the library community is the presence of this tool and its ease of use in providing data to allow each librarian to set his or her own library's financial and performance benchmarks. Our professional organizations urge us to assess our performance, and the NCES surveys academic libraries biennially and provides the data for us to use; what are we waiting for?

\section{Notes}

1. ACRL Undergraduate Librarians Discussion Group, "Guidelines for University Library Services to Undergraduate Students" (June 2005). Available online from www.ala.org/ala/acrl/ acrlstandards/ulsundergraduate.htm. [Accessed 1 August 2006].

2. ACRL Board of Directors, "Standards for Libraries in Higher Education" (June 2004). Available online from www.ala.org/ala/acrl/acrlstandards/standardslibraries.htm. [Accessed 1 August 2006].

3. National Center for Education Statistics, "Library Statistics Program. Compare Academic Libraries" (no date given). Available online from www.nces.ed.gov/surveys/libraries/compare/ index.asp?LibraryType=Academic. [Accessed 1 August 2006].

4. "America's Best Colleges," U.S. News \& World Report 137, no. 6 (Aug. 30, 2004): 90-100.

5. ACRL Undergraduate Librarians Discussion Group, "Guidelines for University Library Services to Undergraduate Students."

6. ACRL Board of Directors, "Standards for Libraries in Higher Education."

7. National Center for Education Statistics, "Library Statistics Program. Compare Academic Libraries."

8. "America's Best Colleges," 90-100. 
9. "America's Best Colleges," 90-100.

10. Association of Research Libraries, "ARL Statistics" (last updated Oct. 13, 2005). Available online from www.arl.org/stats/arlstat/. [Accessed 1 August 2006].

11. "America's Best Colleges," 90-100.

12. National Center for Education Statistics, "Library Statistics Program. Compare Academic Libraries."

13. "America's Best Colleges," 90-100.

14. National Center for Education Statistics, "Library Statistics Program. Compare Academic Libraries."

15. ACRL Undergraduate Librarians Discussion Group, "Guidelines for University Library Services to Undergraduate Students."

16. ACRL Board of Directors, "Standards for Libraries in Higher Education."

17. Andrew Albanese, "Harvard, Yale Still Top ARL," Library Journal 130, no. 13 (Aug. 2005). Available online from www.proquest.umi.com/. [Accessed 27 January 2006].

18. Peter Hernon and Robert E. Dugan, An Action Plan for Outcomes Assessment in Your Library (Chicago: American Library Association, 2002).

19. William N. Nelson and Robert W. Fernekes, Standards and Assessment for Academic Libraries: A Workbook (Chicago: Association of College and Research Libraries, 2002).

20. Donald L. DeWitt, Evaluating the Twenty-First Century Library: The Association of Research Libraries New Measures Initiative, 1997-2001 (Binghamton, N.Y.: Haworth Information Press, 2002).

\begin{tabular}{|l|l|l|}
\hline \multicolumn{3}{|c|}{ Liberal Arts Colleges from 2004 U.S. News \& World Report } \\
Used in NCES Analyses \\
\hline \hline $\begin{array}{c}\text { Top Third Liberal Arts } \\
\text { USN } \boldsymbol{W} \boldsymbol{R} \text { (N = 15) }\end{array}$ & $\begin{array}{c}\text { Middle Third Liberal Arts } \\
\text { USN } \boldsymbol{W} \boldsymbol{R} \text { (N = 15) }\end{array}$ & $\begin{array}{c}\text { Bottom Third Liberal Arts } \\
\text { USN\&WR (N = 16) }\end{array}$ \\
\hline Williams College (MA) & Colby College (ME) & Bard College (NY) \\
\hline Amherst College (MA) & Hamilton College (NY) & Connecticut College \\
\hline Swarthmore College (PA) & Bryn Mawr College (PA) & Whitman College (WA) \\
\hline Wellesley College (MA) & Bates College (ME) & Franklin and Marshall (PA) \\
\hline Carleton College (MN) & Oberlin College (OH) & Furman University (SC) \\
\hline Bowdoin College (ME) & $\begin{array}{l}\text { Mount Holyoke College } \\
\text { (MA) }\end{array}$ & Dickinson College (PA) \\
\hline Davidson College (NC) & Trinity College (CT) & Union College (NY) \\
\hline Haverford College (PA) & Bucknell University (PA) & Centre College (KY) \\
\hline Wesleyan University (CT) & Macalester College (MN) & DePauw University (IN) \\
\hline Middlebury College (VT) & Barnard College (NY) & Occidental College (CA) \\
\hline Vassar College (NY) & Kenyon College (OH) & Gettysburg College (PA) \\
\hline Smith College (MA) & $\begin{array}{l}\text { College of the Holy Cross } \\
\text { (MA) }\end{array}$ & Rhodes College (TN) \\
\hline Washington and Lee (VA) & Lafayette College (PA) & Skidmore College (NY) \\
\hline Colgate University (NY) & Colorado College & Sarah Lawrence (NY) \\
\hline Grinnell College (IA) & University of the South (TN) & Wabash College (IN) \\
\hline & & Denison University (OH) \\
\hline
\end{tabular}

